\title{
Treatment Wetland effluent quality improvement by usage sorbents of various origin
}

\author{
Magda Kasprzyk ${ }^{1, *}$ \\ ${ }^{1}$ Gdansk University of Technology, Faculty of Civil and Environmental Engineering, Narutowicza 11/12 st. 80-233 Gdansk, Poland
}

\begin{abstract}
TWs are finding as low-cost and also effective system to treat domestic wastewater. The aim of this study is to find suitable adsorbing material for application in an additional treatment unit where treatment wetlands do not provide sufficient $\mathrm{PO}_{4}{ }^{3-}$ reduction level. Material $\mathrm{M} 1$ is a fine-grained by-product of thermal treatment of carbonate-siliceous rock (opoka) with high content of calcium carbonate $\mathrm{CaCO}_{3}$ in temperature $700^{\circ} \mathrm{C}$. Particular disadvantage of material M1 can be very high level of $\mathrm{pH}$ (11-12) and causing alkaline solution. Material M2 is lanthanum-modified bentonite (LMB) and was already used for reducing content of phosphorus compounds in lakes and other water bodies to treat effects of eutrophication process. Lanthanum-modified bentonite consists mostly $\mathrm{SiO} 2$ and $\mathrm{Al}_{2} \mathrm{O}_{3}(\sim 80 \%)$. The study was conducted on effluent from small $(60$ pe) treatment wetland (TW) in northern Poland where Hybrid Treatment Wetland (HTW) system was provided. Sorption capacity of material M1 was low and equal $0.9 \mathrm{mg} / \mathrm{g}$. For material M2 this parameter reached value of $2.1 \mathrm{mg} / \mathrm{g}$. Lanthanum-modified bentonite (M2) has shown better abilities to reduce phosphates from wastewater that material M1 - material containing mostly calcium oxide. Also performed study revealed that presence of others contaminations in wastewater is causing difficulties in phosphates removal.
\end{abstract}

\section{Introduction}

In recent years, the popularity of treatment wetlands (TWs) has been increasing as an alternative solution for rural areas and small towns [1,2]. Locating conventional (explain) wastewater treatment plants (WWTPs) in such places is not economically justified and septic tanks used in households usually leak contamination into groundwater. Thus, TWs is a low-cost and effective system to treat domestic wastewater. It has been proven that the most efficient treatment is provided by Hybrid Treatment Wetland (HTW) where the system is composed of at least two beds: subsurface vertical flow bed (SSVF) and subsurface horizontal flow bed (SSHF) $[2,3]$. The first stage ensures suitable conditions for the nitrification process, while the second stage ensures suitable conditions for the denitrification process, removal of organic matter and suspended solids. According to Kadlec and Wallace (2009) [4] also in the SSVF bed denitrification processes occurs, due to saturation of the bed at the bottom layers. The effect of HTW (combined VF-HF system) is focused especially on nitrogen compounds removal $[2,3,5]$. Unfortunately, the removal efficiency of phosphorus compounds concentration in the effluent from HTWs as well as in small WWTP below 2000 PE (person equivalent) is very often inadequate $[1,6]$.

Eutrophication is caused by phosphorus compounds as well as nitrogen. Frequently, nutrients removal concentrates only on nitrogen, although phosphorus has a similar effect on water bodies. Considering the current recommendations [7], which concerns about Baltic Sea protection to prevent eutrophication effects, the $70 \%$ reduction of phosphorus must be provided already for small wastewater treatment plants up to $300 \mathrm{PE}$. Baltic Sea Action Plan obligates Poland to over $40 \%$ reduction in phosphorus emission.[7].

An alternative, but recently interesting method to remove phosphorus compounds from various type of wastewater is applying materials with high sorption capacity. A few sources of adsorbents can be distinguished: (1) anthropogenic, such as AAC (autoclaved aerated concrete) [8], LECA [9], and Pollytag [10] (2) natural, such as rock opoka [11, 12] and POLONITE [13], as well as (3) by-product sources eg. fly ash [14] and blast furnace slag [15]. By-products and waste materials are adsorbents which should arouse interest due to the idea of circular economy and efficient phosphorus recovery will follow this concept, due to increasing awareness of its supply running out. It is estimated that phosphorus supplies may be exhausted within the next 100 years.

Thus, the study concerns finding a suitable adsorbing material for application in an additional treatment unit where treatment wetlands do not provide sufficient $\mathrm{PO}_{4}{ }^{3-}$ reduction level. The aim of the performed investigation was to compare two different materials, the first one is well known material with proven effectiveness for lakes restoration but relatively expensive one, the second one is waste material with $\mathrm{P}$ removal potential. The idea of

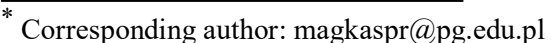


this study was to assess their applicability by kinetic equation and quality of the effluent but also to attempt fulfil the assumptions of circular economy.

The design of the experiment is multistage. In the first stage the applicability and comparison of the two materials (one well know and expansive and the second not investigated yet and the byproduct/reject material from Rockfos ${ }^{\circledR}$ production). They have been already publish some preliminary results from second stage of investigation concerning the specific features of the constructed wetlands - it was predicted that both materials should be used in posttreatment in special facility with adequate contact time and sedimentation [16,17].

\section{Materials and methods}

\subsection{Materials}

Rockfos ${ }^{\circledR}$ is produced in the process of decarbonisation (firing at high temperature $\sim 700^{\circ} \mathrm{C}$ ) of natural silica rock-carbonate. This material is highly reactive to phosphorus compounds as it contains large amounts of elements such as calcium, silicon, aluminium and iron (Fig. 1). According to the producer's requirements, it can be used to build P-filters to remove phosphorus and bacteriological contaminants from domestic and industrial wastewater [18].

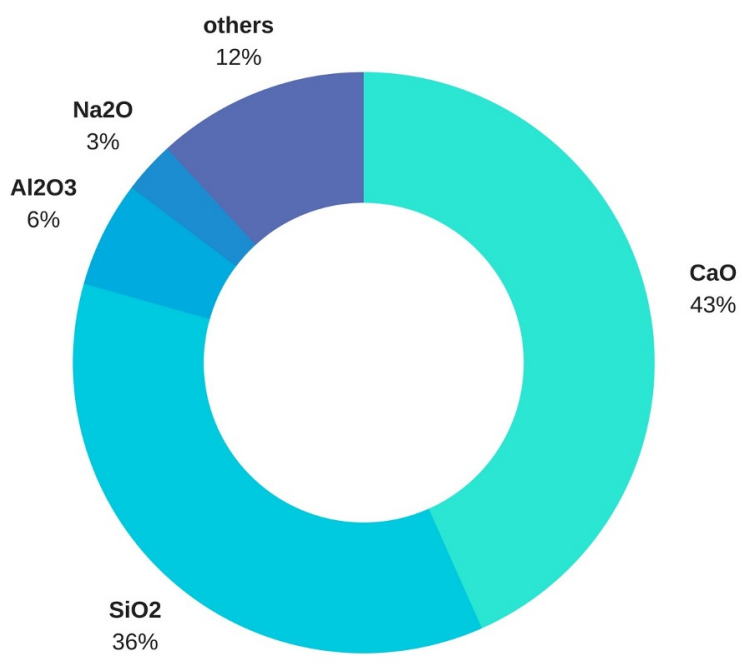

Fig. 1. Chemical composition of Rockfos ${ }^{\circledR}$

Material M1 is a fine-grained by-product of Rockfos ${ }^{\circledR}$ production. This fraction $(0-2 \mathrm{~mm})$ consists mainly of calcium oxide $\mathrm{CaO}$ (over $80 \%$ ), resulting from the decomposition of $\mathrm{CaCO} 3$ during the heating process. A major disadvantage of $\mathrm{M} 1$ is its very high $\mathrm{pH}$ (11-12) making the solution alkaline [18]. Testing a waste material (byproduct) is related to the definition of circular economy.

Material M2 is a lanthanum-modified bentonite clay (LMB) developed by the Land and Water Division of Australia's CSIRO (Commonwealth Scientific and Industrial Research Organisation) and this particular adsorbing material has already been used to reduce the phosphorus compounds content in lakes and other water bodies to treat the effects of eutrophication [19]. In the reaction of binding phosphates by lanthanum from LMB with the molar ratio $1: 1$, a rare-earth complex known as rhabdophane is formed [20]. Also, lanthanum concentration in the solution remains very low, due to locking La particles in the bentonite clay structure [21]. $\mathrm{M} 2$ consists mostly of $\mathrm{SiO}_{2}$ and $\mathrm{Al}_{2} \mathrm{O}_{3}$ (Fig. 2). The LMB $\mathrm{pH}$ is close to neutral (7.0-7.5) but can be successfully used in a wide $\mathrm{pH}$ range from 5 to 9 [2224].

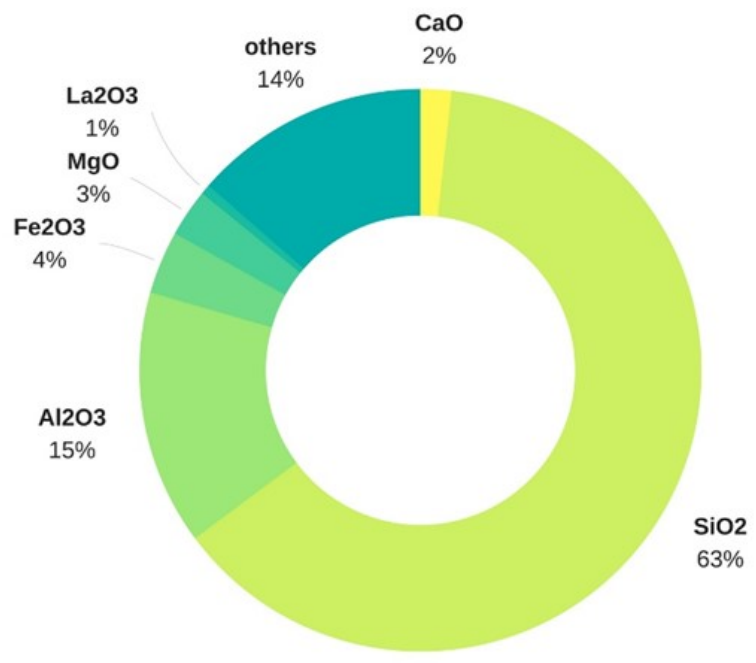

Fig. 2. Chemical composition of material M2

Several studies have been developed to prove nontoxic character of the lanthanum-modified bentonite clay and, in conclusion, to classify LMB as not hazardous [25-27].

\subsection{Methods}

The study was conducted on an effluent from a small wastewater treatment wetland (WTW) for 60 pe in northern Poland where Hybrid Treatment Wetland (HTW) system was provided (coordinates: $54^{\circ} 39^{\prime} 50^{\prime \prime} \mathrm{N}$; $18^{\circ} 07^{\prime} 13^{\prime \prime E}$ ). Sedimentation and flotation processes in the mechanical part of the treatment (three-chamber sedimentation tank) are followed by a biological system (filtration, sorption, oxidation, and reduction processes). The assumed conception is based on two stages: subsurface vertical flow bed and subsurface horizontal flow bed. The natural environment and its biodiversity provide a successful process of treatment, that the effluent from HTW can be directed to the drainage system.

Samples of the wastewater for research were taken after the mechanical treatment and before the discharge to the drainage system (outflow/effluent). The basic parameters of the wastewater measured before and after HTW are presented in Table 1. 
Table 1. Average physical and chemical indicator of wastewater quality in the inflow and effluent from HTW, Pomerania, Poland

\begin{tabular}{|l|c|c|c|c|}
\hline parameter & unit & inflow & $\begin{array}{c}\text { effluent } \\
\text { from HTW }\end{array}$ & $\begin{array}{c}\text { reduction } \\
\text { rate }\end{array}$ \\
\hline Temperature & ${ }^{\circ} \mathrm{C}$ & 20.8 & 18.9 & - \\
\hline $\mathrm{pH}$ & - & 7.17 & 7.17 & - \\
\hline Conductivity & $\mu \mathrm{S} / \mathrm{cm}$ & 1656 & 1226 & - \\
\hline Color & $\mathrm{mgPt} / \mathrm{L}$ & 392 & 34 & $91 \%$ \\
\hline Turbidity & $\mathrm{mg} / \mathrm{L}$ & 104.4 & 6.5 & $94 \%$ \\
\hline $\mathrm{TSS}^{2}$ & $\mathrm{mg} / \mathrm{L}$ & 28.0 & 9.0 & $68 \%$ \\
\hline $\mathrm{PO}^{3-}-\mathrm{P}$ & $\mathrm{mg} / \mathrm{L}$ & 26.6 & 4.34 & $84 \%$ \\
\hline $\mathrm{COD}^{3}$ & $\mathrm{mg} / \mathrm{L}$ & 329.0 & 20.8 & $94 \%$ \\
\hline $\mathrm{NH}_{4}{ }^{+}-\mathrm{N}$ & $\mathrm{mg} / \mathrm{L}$ & 138.9 & 18.9 & $86 \%$ \\
\hline $\mathrm{NO}_{3}{ }^{-}-\mathrm{N}$ & $\mathrm{mg} / \mathrm{L}$ & 0.75 & 36.1 & - \\
\hline $\mathrm{NO}_{2}{ }^{-}-\mathrm{N}$ & $\mathrm{mg} / \mathrm{L}$ & 0.13 & 0.42 & - \\
\hline
\end{tabular}

The results indicate that HTW provides relatively high efficiency of contaminants removal, although the pollution load of discharged wastewater still does not meet the Polish and European requirements Polish Regulation (Year 2014, item 1800) [28], Council Directive 91/271/EEC (European Commission, 1991) [29]. The study concentrates on removal of phosphates in TWs despite the regulations report total phosphorus. Form of phosphorus which occurs mostly in wetland are phosphates, both in organic and inorganic compounds. It has been proven that free orthophosphate is the only bioavailable form for plants in wetlands beds [30]. Moreover, the performed research was conducted on the TW effluent, thus most of organic phosphorus was removed in mechanical part of the treatment system.

The described HTW is located near Puck Bay. This specific water body is characterized with a high contamination level, as it is closed with the Hel Peninsula thus having limited connection with the Baltic Sea.

Experimental trials were carried out in steady conditions. To batch reactors filled with $1.0 \mathrm{~L}$ of effluent from HTW, $0.5 \mathrm{~g}$ of a selected adsorbing material was added and mixed for 5 minutes. Sampling was done after $5,10,30,60,120$ and 300 minutes to define the materials sorption capacity and to assess their adsorption kinetics by the pseudo-second order model. The parameters such as $\mathrm{pH}$, conductivity (EC), color, turbidity, and total suspended solids (TSS) were measured before and after the addition of the adsorbing materials to evaluate their influence over the wastewater quality. The concentration of $\mathrm{PO}_{4}{ }^{3-}$ was analysed by $\mathrm{HACH}$ Lange cuvette tests, while others parameters were measured using $\mathrm{HACH}$ Lange DR 3900 spectrophotometer and WTW Multi 350i compact precision portable meter. The laboratory studies were conducted at ambient temperature.

\subsection{Kinetic study - pseudo-second order model}

The adsorption kinetics data analysis of both materials were presented with the pseudo-second order model, which allows predicting the sorption capacity and indicates constant parameters.

Sorption capacity of phosphates for each material was calculated according to equation (1) [31]:

$$
q_{e}=\left(C_{0^{-}} C\right) / m \cdot V
$$

where: $\mathrm{q}_{\mathrm{e}}$ - sorption capacity $[\mathrm{mg} / \mathrm{g}], \mathrm{V}$ - volume of solution [L], $\mathrm{C}_{0}-$ initial concentration of $\mathrm{PO}_{4}-\mathrm{P}[\mathrm{mg} / \mathrm{L}]$; $\mathrm{C}$ - final concentration of $\mathrm{PO}_{4}-\mathrm{P}[\mathrm{mg} / \mathrm{L}], \mathrm{m}-$ mass of sorption material [g].

The kinetics was investigated at solution $\mathrm{pH}$. The formula to describe the adsorption kinetics is the following $[23,32,33]$ :

$$
\mathrm{dq}_{\mathrm{t}} / \mathrm{dt}=\mathrm{k} \cdot\left(\mathrm{q}_{\mathrm{e}}-\mathrm{q}_{\mathrm{t}}\right)^{2}
$$

where: $\mathrm{q}_{\mathrm{t}}$ - adsorption capacity at time $\mathrm{t}[\mathrm{mg} / \mathrm{g}], \mathrm{q}_{\mathrm{e}}-$ adsorption capacity at equilibrium $[\mathrm{mg} / \mathrm{g}], \mathrm{k}-$ equilibrium rate constant of pseudo-second order reaction $[\mathrm{g} / \mathrm{mg} \cdot \mathrm{min}]$.

Integrating equation (2) for the boundary condition $t$ $=0$ to $\mathrm{t}=\mathrm{t}$ and $\mathrm{q}_{\mathrm{t}}=0$ to $\mathrm{q}_{\mathrm{t}}=\mathrm{q}_{\mathrm{t}}$, the formula becomes:

$$
1 /\left(\mathrm{q}_{\mathrm{e}}-\mathrm{q}_{\mathrm{t}}\right)=1 / \mathrm{q}_{\mathrm{e}}+\mathrm{k}_{\mathrm{t}}
$$

From equation (3) linear form can be obtained:

$$
\mathrm{t} / \mathrm{q}_{\mathrm{t}}=1 / \mathrm{k} \cdot \mathrm{q}_{\mathrm{e}}^{2}+\mathrm{t} / \mathrm{q}_{\mathrm{e}}
$$

The analysis of a straight plot of $t / q_{t}$ against time ( $t$ ) allows calculating the value of parameters $\mathrm{k}, \mathrm{q}_{\mathrm{e}}$ and the coefficients of determination $\mathrm{R}^{2}$.

\section{Results and discussion}

The results indicate different efficiency of phosphates removal for both materials. In the performed study, the initial phosphates concentration of TW effluent was approx. $2.5 \mathrm{mg} / \mathrm{L}$. The obtained sorption capacity of M1 was low and equal to $0.9 \mathrm{mg} / \mathrm{g}$. The final concentration of $\mathrm{PO}_{4}{ }^{3-}$ was close to $2.1 \mathrm{mg} / \mathrm{L}$ after 5 hours contact time which provides $17 \%$ phosphates reduction efficiency. The dose of the adsorbing material was relatively low $(0.5 \mathrm{~g})$, although the value of removed $\mathrm{PO}_{4}{ }^{3-}$ was below expectations.

Various tested materials with high contents of calcium oxide presented a significant ability to remove phosphorus compounds $[9,12,31,34]$. In the previous study performed on synthetic wastewater, the sorption capacity of this particular material reached $9.6 \mathrm{mg} / \mathrm{g}$. The research proceeded in steady conditions with a short contact time of 1 hour. Although the described laboratory trials were conducted with an artificial Psolution $\left(\mathrm{KH}_{2} \mathrm{PO}_{4}\right)$ [16], such observations may reveal a possible influence of wastewater quality and the concentration of other compounds (eg. of nitrogen or organic matter) on the removal efficiency of phosphates.

The kinetic data simulated by the pseudo-second order model fitted the experiment results well. For M1, 
the coefficient of determination $\left(\mathrm{R}^{2}\right)$ was equal to 0.95 and correlation coefficient $\left(\mathrm{r}_{\mathrm{xy}}\right)$ was 0.97 , as shown in Figure 3. The equilibrium $\mathrm{q}_{\mathrm{e}}$ value was $0.90 \mathrm{mg} / \mathrm{g}$ (Table 2 ), which was nearly the same as the sorption capacity obtained from the experimental values.

Table 2. Kinetic parameters for pseudo-second order model of phosphates adsorption

\begin{tabular}{|c|c|c|c|c|}
\hline material & $\mathrm{q}_{\mathrm{e}}[\mathrm{mg} / \mathrm{g}]$ & $\mathrm{k}\left[\mathrm{g} / \mathrm{mg}{ }^{*} \min \right]$ & $\mathrm{R}^{2}$ & $\mathrm{r}_{\mathrm{xy}}$ \\
\hline M1 & 0.9 & 1.24 & 0.95 & 0.97 \\
\hline M2 & 2.1 & 0.23 & 0.99 & 0.99 \\
\hline
\end{tabular}

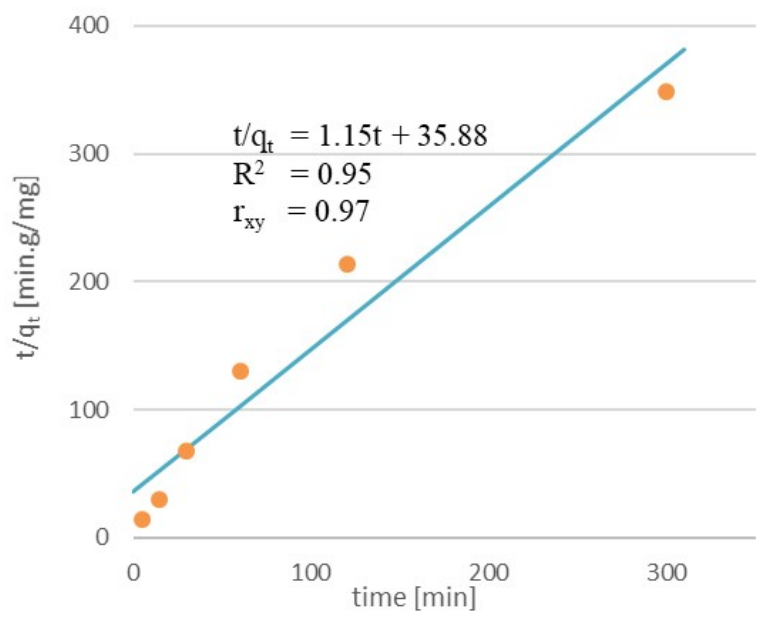

Fig. 3. Adsorption kinetics for pseudo-second order model of $\mathrm{PO}^{3-}$ onto material M1

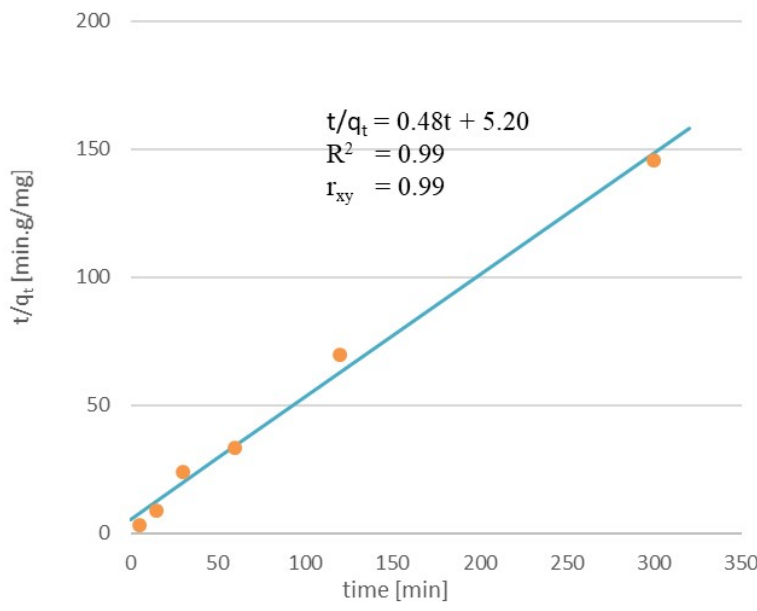

Fig. 4. Adsorption kinetics for pseudo-second order model of $\mathrm{PO}_{4}{ }^{3-}$ onto material M2

For M2 the sorption capacity was equal to $2.06 \mathrm{mg} / \mathrm{g}$, while the concentration of $\mathrm{PO}_{4}{ }^{3-}$ dropped to $1.5 \mathrm{mg} / \mathrm{L}$ during the experiment. The effectiveness of phosphates removal reached $41 \%$ with the same dose and contact time. Similarly to M1, theoretical ability (obtained from research on synthetic wastewater) of $\mathrm{M} 2$ to reduce $\mathrm{PO}_{4}{ }^{3-}$ was significantly higher. The study conducted by Kasprzyk et al. (2018) [16] gave the sorption capacity of M2 at the level of $9.1 \mathrm{mg} / \mathrm{g}$. While, according to
Haghseresht et al. (2009) [23], the adsorption capacity of M2 cannot exceed $10.6 \mathrm{mgP} / \mathrm{g}$. From the results obtained by Kurzbaum and Bar Shalom (2016) [35], the maximum sorption capacity of LMB reached $14.4 \pm 4.7$ $\mathrm{mg} \mathrm{PO}_{4} / \mathrm{g}$. Also Ross et al. (2008) [24] observed a decrease of phosphates reduction efficiency of M2 while using it for lake water treatment, and pointed to the presence of humic acid.

Also in the case of M2 pseudo-second order model, both the coefficient of determination $\left(\mathrm{R}^{2}\right)$ and correlation coefficient $\left(\mathrm{r}_{\mathrm{xy}}\right)$ were close to 1.0 (Fig. 4) and displayed satisfactory matching of the kinetic data. The equilibrium $\mathrm{q}_{\mathrm{e}}$ was equal to the sorption capacity calculated from the research data (Table 2).

The effect of both materials on the $\mathrm{pH}$ values was quite different. M1 caused a relatively high increase of $\mathrm{pH}$ of the solution despite a small dose of the sorption material used $(0.5 \mathrm{~g})$. The initial $\mathrm{pH}$ of the HTW effluent was close to neutral and equal to 7.2. Already after 5 minutes of the contact time, $\mathrm{pH}$ level reached almost 8.4 and during further sampling, $\mathrm{pH}$ slowly increased to the value of 8.6 after 5 hours of sedimentation (Fig. 5).

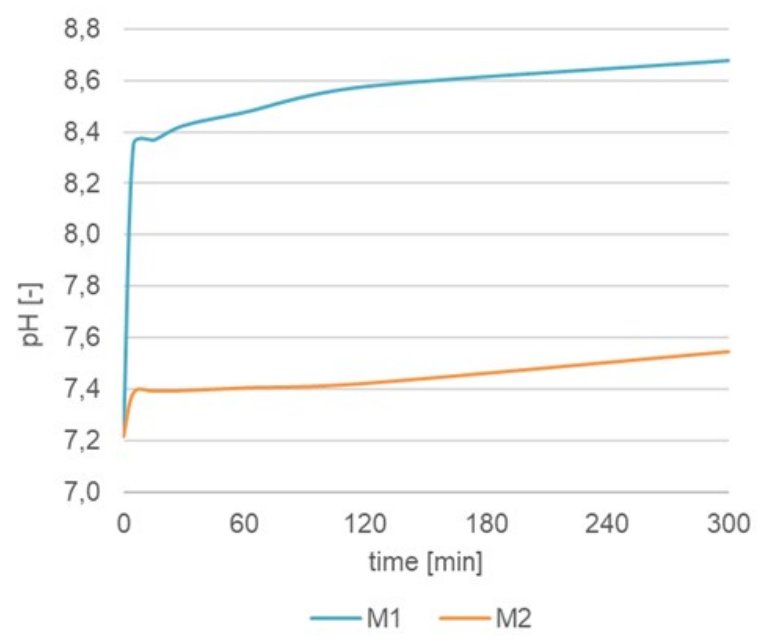

Fig. 5. Influence of adsorbing materials on $\mathrm{pH}$ of the effluent from HTW

This particular disadvantage of M1 is related to a significant content of calcium oxide, although its presence determines the ability to remove substantial amounts of $\mathrm{PO}_{4}{ }^{3-}[36,37]$. The research described by Jucherski et al. (2017) [11], reports on the application of alkaline filtration materials for phosphorus removal, where a material with high contents of $\mathrm{Ca}(\sim 50 \%)$ caused an increase of the solution $\mathrm{pH}$ to almost 13. Also, the authors pointed out that such materials may be used as the last stage in a small treatment facility on condition the effluent $\mathrm{pH}$ value is less than 8.5. Possible applications of $\mathrm{M} 1$ require adjusting $\mathrm{pH}$ to an acceptable level.

In the case of M2, the effect on $\mathrm{pH}$ was slight. An insignificant increase to the value of 7.55 was observed (Fig. 5). According to Douglas et al. (2016) [19] and Van Oosterhout and Lürling (2013) [38], M2 caused only a minor increase or had no effect on the solution 
$\mathrm{pH}$. The performed studies usually concentrate on how $\mathrm{pH}$ influences phosphorus removal efficiency using LMB, rather than how the material impacts the solution, considering $\mathrm{pH}$ level as one of the most important parameters of the adsorption processes [23, 24, 33]. No impact on the $\mathrm{pH}$ values is an extremely important advantage, although the solution $\mathrm{pH}$ may determine the effectiveness of $\mathrm{M} 2$ (with the optimal $\mathrm{pH}$ range of 5-7).

The initial conductivity of the HTW effluent was equal to $928 \mu \mathrm{S} / \mathrm{cm}$. M1 has shown a meager increase to the value of $945 \mu \mathrm{S} / \mathrm{cm}$ at the beginning of the contact time, and after 1 hour of sedimentation, the conductivity stabilized at the level of $941 \mu \mathrm{S} / \mathrm{cm}$. M2 displayed almost no influence on EC (Fig. 6). Nevertheless, it should be pointed out that small doses of the reactive materials were used. The application of larger amounts of those adsorbents (especially M1) may have a negative effect on the quality of the effluent.

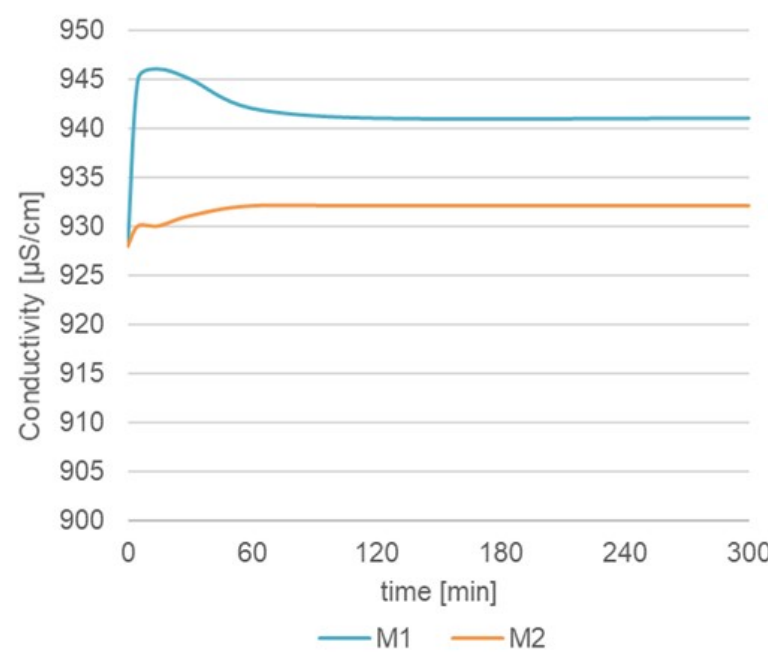

Fig. 6. Influence of adsorbing materials on EC of the effluent from HTW

Both the tested materials did not significantly affect the color and turbidity of the effluent from the HTW. Initial values were equal to $24 \mathrm{mgPt} / \mathrm{L}$ and $5.3 \mathrm{mg} / \mathrm{L}$ respectively. During the contact time, slight fluctuations of those parameters were observed. At the end of the experiment, the color and turbidity for M1 was equal to $36 \mathrm{mgPt} / \mathrm{L}$ and $7.1 \mathrm{mg} / \mathrm{L}$, while for $\mathrm{M} 2-38 \mathrm{mgPt} / \mathrm{L}$ and $8.1 \mathrm{mg} / \mathrm{L}$ respectively.

In the case of total suspended solids (TSS in the first taken samples (after 5 minutes of sedimentation), a high increase of the TSS values was observed for both materials (from $5 \mathrm{mg} / \mathrm{L}$ to approx. $23 \mathrm{mg} / \mathrm{L}$ ). This effect could be caused by the amount of dissolving matter. It was necessary to extend the sedimentation time. After 5 hours, in both cases the values of TSS were close to initial.

In case of long term use of those materials, the maintenance costs will be entirely different due to their futures like pace of origin eg. M2 is from Australia what means costly transportation which also create big carbon food print. Assumed total daily inflow of the wastewater in Kniewo HTW was equal to $7.0 \mathrm{~m}^{3} / \mathrm{d}$ which yields
2,500 $\mathrm{m}^{3}$ per year. Based on the effluent phosphates concentration, the load of $\mathrm{PO}_{4}-\mathrm{P}$ can reach $10 \mathrm{~kg} /$ year. The sorption capacity of M1 and M2 achieved from the study was equal to 0.9 and $2.1 \mathrm{mg} / \mathrm{g}$ respectively, which concludes with the usage over 10 tons of M1 and almost 5 tons of M2.

The cost of M1 usage despite to twice the M2 requirement might be significantly lower. M1 is a byproduct and waste material with no specific purpose. On the other hand, the M2 unit price may reach $2750 € /$ ton [39] and gives an annual maintenance cost equal to $14,000 €$ (Table 3). Possibility of material recovery or reuse need further analysis.

Table 3. Maintenance and cost analysis

\begin{tabular}{|c|c|c|c|c|c|}
\hline $\begin{array}{c}\text { sorption } \\
\text { capacity }\end{array}$ & $\begin{array}{c}\text { material } \\
\text { required }\end{array}$ & price & $\begin{array}{c}\text { annual } \\
\text { cost }\end{array}$ & $\begin{array}{c}\text { costs per } \\
\mathrm{m}^{3} \text { of } \\
\text { treated } \\
\text { effluent }\end{array}$ \\
\hline & $\mathrm{mg} / \mathrm{g}$ & $€$ & $€ / \mathrm{m}^{3}$ \\
\hline M1 & 0.9 & $\begin{array}{c}\sim 10 \text { tons } \\
\text { per year }\end{array}$ & $\begin{array}{c}1 € / \text { ton }+ \\
\text { transport } \\
\text { cost }\end{array}$ & $\sim 700$ & 0.3 \\
\hline M2 & 2.1 & $\begin{array}{c}\sim 5 \text { tons } \\
\text { per year }\end{array}$ & $2750 € /$ ton & $\sim 14000$ & 6 \\
\hline
\end{tabular}

\section{Conclusions}

The results presented in this study indicate a better ability to reduce phosphates from the HTW effluent displayed by lanthanum-modified bentonite (M2) than M1 - a material containing mostly calcium oxide. Obtained from the kinetic data, the equilibrium sorption capacity $\left(\mathrm{q}_{\mathrm{e}}\right)$ of $\mathrm{M} 1$ was low and equal to $0.9 \mathrm{mg} / \mathrm{g}$, while of M2 - $2.1 \mathrm{mg} / \mathrm{g}$. The pseudo-second order model fitted the experiment results of both materials M1 and M2 well, due to the coefficient of determination $\left(\mathrm{R}^{2}\right)$ values equal to 0.95 and 0.99 respectively and high correlation coefficient $\left(\mathrm{r}_{\mathrm{xy}}\right)$ for M1 -0.97 , for M2 -0.99 .

The performed study also revealed that the presence of other contaminants in wastewater causes difficulty in phosphates removal. Due to this fact their influence on the processes of phosphates binding should be verified and subsequently an appropriate dose of the adsorbing material for proper wastewater treatment should be established.

The influence of M1on the pH of HTW effluent was substantial as it increased from the initial value 7.2 to 8.6. It was due to the high content of calcium oxide. As a result, the application of M1 gives an alkaline solution. The other parameters showed no significant impact on the quality of the HTW effluent, for both materials.

\section{Acknowledgements}

Publication supported by the Polish Ministry of Science and Higher Education as a part of the program of activities disseminating science from the project „Organization of the First International Science 
Conference - Ecological and Environmental Engineering”, 26-29 June 2018, Kraków.

The research was carried out within the subtask 2.3 of the project entitled "Integrated technology for improved energy balance and reduced greenhouse gas emissions at municipal wastewater treatment plants" with the acronym "BARITECH" co-funded by the Norwegian funds, under the Polish-Norwegian Cooperation Research carried out by the National Centre for Research and Development [197025/37/2013].

Special thanks to KUFEL Ceramics Company, the sole producer of Rockfos ${ }^{\circledR}$ in Poland for the free of charge sharing of research material.

\section{References}

1. M. Gajewska, Ł. Kopeć, H. Obarska-Pempkowiak. Annual Set of Environment Protection, 13 (1) 207225. (2011).

2. M. Gajewska, K. Jóźwiakowski, A. Ghrabi, F. Masi, Environmental Science and Pollution Research, 41, No. 3:19-3 (2015)

3. 3. J. Vymazal. Ecological Engineering 25, pp. 478490. (2005)

4. R.H. Kadlec, S. Wallace. Treatment wetlands, 2nd edn. CRC Press Taylor \& Francis Group, Boca Raton, pp. 267-347. (2009)

5. M. Gajewska, H. Obarska-Pempkowiak. Annual Set The Environmental Protection, 11 (1), 875-888. (2009)

6. M. Gajewska, H. Obarska-Pempkowiak, Envir. Protection Engineering, 37, no. 3, 27-36. (2011)

7. HELCOM Recommendation 28E/6. Adopted 15 November 2007. On-site wastewater treatment of single family homes, small businesses and settlements up to 300 Person Equivalents (P.E.).

8. G. Renman, A. Renman, 2012. Sustainable use of crushed autoclaved aerated concrete (CAAC) as a filer medium in wastewater purification, WASCON 2012 Conference proceeding.

9. A. Karczmarczyk, A. Bus. University of Life Sciences - SGGW Land Reclamation. 46 (1), 57-67. (2014)

10. A. Bus, A. Karczmarczyk, A. Baryła. Inzynieria Ekologiczna 39: 33-41. (2014)

11. A. Jucherski, M. Nastawny, A. Walczowski, K. Jozwiakowski, M. Gajewska. Ochrona Srodowiska 39, No. 1, pp. 33-38. (2017)

12. K. Jóźwiakowski, M. Gajewska, A. Pytka, M. Marzec, M. Gizińska-Górna, A. Jucherski, A. Walczowski, M. Nastawny, A. Kamińska, S. Baran. Ecological Engineering, 98, 290-296. (2017)

13. A. Karczmarczyk, A. Bus, A. Baryła,. Ecological Engineering 86, 69-74. (2016)

14. A. Drizo, C. Frost, J. Grace, K. Smith. Water Research. 33:3595-3602 (1999)
15. A. Drizo, C. Forget, RP. Chapuis, Y. Comeau. Water Research 40:1547-1554 (2006)

16. M. Kasprzyk, J. Wȩgler, M. Gajewska. E3S Web of Conferences (Vol. 26). (2018)

17. M. Kasprzyk, M. Gajewska. Journal of Ecological Engineering, 18(4), p. 82-89. (2017).

18. Product Data Sheet Rockfos ${ }^{\circledR}$ http://www.ceramikakufel.pl/rockfos/

19. G.B. Douglas, M. Lurling, B.M. Spears. Water Research 97, 47-54. (2016)

20. G.B. Douglas, J.A. Adeney, LR. Zappia. Sediment Remediation Project: 1998/9 Laboratory Trial Report. CSIRO Land and Water. Report No. 6/00 2000 CSIRO (2000)

21. A. Afsar, S. Groves. PWS Report Number: IR, (July 2009). Retrieved from http://www.phoslock.eu/media/7401/Comparison_of $\mathrm{P}-$

inactivation_efficacy_and_ecotoxicity_of_Alum_an d_Phoslock_July_2009.pdf

22. D. Copetti, K. Finsterle, L. Marziali, F. Stefani, G. Tartari, G. Douglas, K. Reitzel, B.M. Spears, I.J. Winfile, G. Crosa, P. D'Haese, S. Yesseri, M. Lürling. Water Research 97, 162-174 (2015)

23. F. Haghseresht, S. Wang, D.D. Do. Applied Clay Science, 46, 369-375. (2009)

24. G. Ross, F. Haghseresht, T. E. Cloete. Harmful Algae, 7 (4), 545-550. (2008)

25. M.J. Barry, B.J. Meehan. Chemosphere 41, 16691674 (2000)

26. M.L. Martin, C.W. Hickey, Determination of HSNO Ecotoxic Thresholds for Granular PhoslockTM, Phase 1: Acute Toxicity, National Institute of Water and Atmospheric Research Ltd. Report prepared for Primaxa Ltd., Hamilton, New Zealand, (2001)

27. M. Zamparas, G. Gavriil, F.A. Coutelieris, I. Zacharias. Applied Surface Science, 335, 147-152. (2015)

28. Polish Regulation of the Minister of the Environment from 18 of November 2014 according limits for discharged sewage into water and soil and on substances harmful to the aquatic environment (year 2014, item 1800) (in Polish) (2014)

29. European Commission 1991. Council directive 91/271/EEC of 21 May 1991 concerning urban wastewater treatment, Off. J. Eur. Union L135 4052. (1991)

30. J. Vymazal. Science of the Total Environment, 380, 48-65. (2007)

31. M. Nastawny, A. Jucherski, A. Walczowski, K. Jóźwiakowski, A. Pytka, M. Gizińska-Górna, M. Marzec, M. Gajewska, A. Marczuk, J. Zarajczyk, Przemysl Chemiczny 94/10/2015, (in Polish) (2015)

32. Y. S. Ho, G. McKay. Resources, Conservation and Recycling, 25 (3-4), 171-193. (1999) 
33. M. Zamparas, A. Gianni, P. Stathi, Y. Deligiannakis, I. Zacharias. Applied Clay Science, 62-63, 101-106. (2012).

34. V. Cucarella, T. Zaleski, R. Mazurek, Annals of Warsaw University of Life Sciences - SGGW Land Reclamation. 38, 11-18. (2007)

35. E. Kurzbaum, O. Bar Shalom. Applied Clay Science, 123, 182-186. (2016)

36. Z. Brogowski, G. Renman. Polish J. of Environ. Studies 13 (1): 15-20 (2004)
37. A. Bus, A. Karczmarczyk. Infrastruktura i Ekologia Terenów Wiejskich, 1 (II), 227-238. (2014)

38. F. Van Oosterhout, M. Lürling, Hydrobiologia, 710, 265-277. (2013)

39. E. Mackay, S. Maberly, G. Pan, K. Reitzel, A. Bruere, N. Corker, G. Douglas, S. Egemose, D. Hamilton, T Hatton-Ellis, B. Huser, W. Li, S. Meis, B. Moss, M. Lürling, G. Phillips, S. Yasseri, B. Spears, Inland Waters 4, 349-356. (2014) 